\title{
Epididymal lithiasis in roosters and efferent ductule and testicular damage
}

\author{
G. A. B. Mahecha ${ }^{1}$, C. A. Oliveira ${ }^{1,2}$, \\ K. Balzuweit ${ }^{3}$ and R. A. Hess ${ }^{4 *}$ \\ ${ }^{1}$ Departmento de Morfologia, ${ }^{2}$ Departmento de Fisiologia, ${ }^{3}$ Departamento de Física, \\ Universidade Federal de Minas Gerais, Belo Horizonte-MG, 30190-003, Brazil; and \\ ${ }^{4}$ Veterinary Biosciences, University of Illinois, 2001 S. Lincoln, Urbana, IL 61802, USA
}

\begin{abstract}
Epididymal stones have been reported in roosters in the USA and Japan. The cause of this dysfunction, which is associated with low fertility, is not known. The hypothesis of the present study is that a potential cause is the aggressive selection of birds over many centuries based upon female egg laying traits, without concern for potential effects on the male. If this hypothesis is correct, one potential consequence would be the presence of epididymal stones only in domesticated fowl and this observation would be worldwide in distribution. The present study investigated epididymal lithiasis in Brazilian crossbreed roosters and two other fowl strains, in addition to several domestic and wild bird species. The efferent ductules contained stones in $94.3 \%$ of the roosters, but stones were absent in all other domestic and wild birds. The stones were irregular in shape, size and colour and consisted mainly of calcium. In affected roosters, the efferent ductules showed
\end{abstract}

epithelial cell vacuolization and sloughing and peritubular mononuclear cell infiltration, culminating with atrophy. Signs of epithelial re-canalization were seen in ductules occluded by abnormal content, such as stones. In the testis, decrease in mass, sloughing of epithelium, mononuclear cell infiltration and tubular atrophy occurred. No correlation was found between the occurrence of stones and a positive test for ELISA IBV (infectious bronchitis virus), or between the number of stones and calcium concentration in water and food, indicating that IBV infection and calcium in the diet were not related to stones formation. This study confirms and extends information about the epididymal lithiasis, which appears to be unique for roosters but to occur around the world. The severity of the lesion points to potentially severe economical impact in the poultry industry.

\section{Introduction}

The domestic fowl (Gallus domesticus) serves as a major source of dietary intake in humans. As a consequence, this avian species has been intensely manipulated by diet, environment and genetic selection to induce rapid growth and yield. Originally, fowl were seasonal breeders, but now, after domestication, they breed throughout the year. Under these artificial conditions, when the domestic rooster reaches the first year of life, they frequently present a rapid decline in fertility, a dysfunction known as premature low fertility syndrome (Muncher et al., 1995). Fertility of roosters exhibiting this syndrome reaches a peak (96\%) within 32 weeks and then declines until they reach an extremely low fertility (5\%) at approximately 110 weeks of age (Rosenstrauch et al., 1994; Muncher et al., 1995).

Several hypotheses have been presented to explain such low fertility in ageing roosters (Froman and Bernier, 1987; Rosenstrauch et al., 1994; Muncher et al., 1995), including sperm abnormality acquired during their passage through the efferent ductules (Kirby et al., 1990). On the other hand,

*Correspondence

Email: r-hess@uiuc.edu a recent study found calcium stones in the epididymides of diverse populations of roosters, a condition that was also associated with low fertility (Janssen et al., 2000). In roosters with epididymal stones, daily sperm production and circulating testosterone concentrations were significantly decreased. Occurrence of stones in the epididymal region of fowl was found in several regions of the USA and Japan (Janssen et al., 2000), indicating that this anomaly may have wider distribution than originally expected. However, the cause of this pathology is unknown. Its economic impact in the poultry industry is potentially quite severe, because of the high incidence of stones in roosters and the long-term effects on fertility.

In Brazil, in addition to intensive confinement of fowl, it is common to use open range, crossbreeding of fowl, whereby the birds are exposed openly to the environment. These fowl are the product of unknown breeds and strains of roosters that have acclimatized for more than 200 years in this country. They live freely on the ground and are not vaccinated. Janssen et al. (2000) have proposed that infectious bronchitis virus (IBV) in the reproductive tract could be the cause of chronic inflammation and calcium stone formation seen in the efferent ductules. Therefore, the crossbred roosters will provide an alternative model for the 
Table 1. Occurrence of epididymal stones in unvaccinated crossbreed roosters from diverse counties of Minas Gerais, Brazil and the respective drinking water hardness, body weight and testis-epididymis mass

\begin{tabular}{|c|c|c|c|c|c|c|c|}
\hline \multirow[b]{2}{*}{ Number $^{\mathrm{a}}$} & \multirow{2}{*}{$\begin{array}{c}\text { Age } \\
\text { (weeks) }\end{array}$} & \multirow{2}{*}{$\begin{array}{l}\text { Body weight } \\
(\mathrm{g})\end{array}$} & \multirow{2}{*}{$\begin{array}{c}\text { Testis-epididymis } \\
\text { mass (g) }\end{array}$} & \multirow{2}{*}{$\begin{array}{l}\text { Number of stones } \\
(x)\end{array}$} & \multicolumn{3}{|c|}{ Water hardness ( $\left.\mathrm{mg} \mathrm{l}^{-1}\right)$} \\
\hline & & & & & $\mathrm{Ca}$ & $\mathrm{Mg}$ & $S$ \\
\hline 1 & 96 & 5100.00 & 18.27 & 245.5 & 148.2 & 11.8 & 0.5 \\
\hline 2 & 96 & 5200.00 & 18.50 & 96.5 & 148.2 & 11.8 & 0.5 \\
\hline 3 & 96 & 5200.00 & 17.85 & 64.0 & 148.2 & 11.8 & 0.5 \\
\hline 4 & 96 & 5600.00 & 1.50 & 8.0 & 148.2 & 11.8 & 0.5 \\
\hline 5 & 96 & 4800.00 & 18.68 & 68.5 & 148.2 & 11.8 & 0.5 \\
\hline 6 & 90 & 2200.00 & 6.56 & 29.0 & 0.04 & 0.002 & 0.0 \\
\hline 7 & 90 & 1700.00 & 3.75 & 28.5 & 0.04 & 0.002 & 0.0 \\
\hline 8 & 96 & 4300.00 & 2.89 & 25.0 & 40.6 & 2.7 & 0.5 \\
\hline 9 & 96 & 3700.00 & 0.94 & 8.5 & 40.6 & 2.7 & 0.5 \\
\hline 10 & 70 & 1800.00 & 0.66 & 8.0 & 40.6 & 2.7 & 0.5 \\
\hline 11 & 70 & 1700.00 & 5.29 & 27.5 & 40.6 & 2.7 & 0.5 \\
\hline 12 & 70 & 2600.00 & 14.80 & 0.0 & 40.6 & 2.7 & 0.5 \\
\hline 13 & 80 & 4100.00 & 6.30 & 20.5 & 8.6 & 5.6 & 0.5 \\
\hline 14 & 80 & 4000.00 & 15.43 & 71.5 & 8.6 & 5.6 & 0.5 \\
\hline 15 & 80 & 4200.00 & 12.78 & 37.0 & 8.6 & 5.6 & 0.5 \\
\hline 16 & 80 & 3850.00 & 5.14 & 25.5 & 8.6 & 5.6 & 0.5 \\
\hline 17 & 98 & 4650.00 & 19.60 & 0.0 & 0.04 & 0.002 & 0.0 \\
\hline 18 & 98 & 4700.00 & 16.46 & NC & 0.04 & 0.002 & 0.0 \\
\hline 19 & 98 & 5600.00 & 14.62 & NC & 0.04 & 0.002 & 0.0 \\
\hline 20 & 100 & 4300.00 & 5.24 & NC & 0.04 & 0.002 & 0.0 \\
\hline 21 & 106 & 4800.00 & 5.44 & NC & 0.04 & 0.002 & 0.0 \\
\hline 22 & 106 & 5200.00 & 0.86 & NC & 0.04 & 0.002 & 0.0 \\
\hline
\end{tabular}

a $1-5=$ Montes Claros county; 6,7 = Belo Horizonte county; 8-12 = Uba county; $13-16=$ Janauba county; 17-21 = Caete county; $(\mathrm{x})=$ means of both sides; $\mathrm{NC}=$ not counted

study of epididymal lithiasis. If they contain epididymal stones but test negative for IBV, then it is possible that the stones are formed through different micro-organisms or by other mechanisms.

The present study investigated the occurrence of stones in Brazilian crossbreed roosters and two other strains of fowl to extend information about the incidence of the epididymal lithiasis and to contribute in the investigation of causes of this abnormality in relation to environmental conditions and IBV infection. Other domestic avian species and several wild birds were also studied to determine whether epididymal stone formation is confined to the domesticated fowl. The results indicate that epididymal stones are formed exclusively in the rooster (G. domesticus). These stones were present in approximately $94.0 \%$ of the roosters examined.

\section{Materials and Methods}

\section{Roosters}

Different strains of roosters were collected from different geographical regions in the state of Minas Gerais, Brazil and were divided into three groups: (1) crossbreeds, (2) White Leghorn and (3) Ross roosters. The first group consisted of 22 unvaccinated 70- to 106-week-old crossbred roosters (products of unknown breeds). In addition to their natural diet (worms, insects and other small invertebrates), the animals received corn as basic food. The water provided was from natural streams with variable concentrations of calcium and manganese (Table 1). The roosters had coexisted with other wild and domestic birds and had been exposed to herbicides and pesticides frequently used on the farms.

The second group included ten unvaccinated 82- to 96-week-old White Leghorn roosters, which were kept in individual cages and received commercial food containing 1000 iu vitamin D3 and 3\% calcium (Socil Guyomarc'H, Belo Horizonte, Brazil). The commercial diet was prepared with corn, soy bran and other cereal grains. The fowl were supplied with water with low concentrations of calcium and manganese (Table 2).

Group three comprised three vaccinated 70-week-old broiler roosters of the Ross strain (imported as chicks from Ireland), which were obtained from a commercial farm (Alimenta avicola SA de Minas Gerais, Carmo do Cajuru, Brazil). They received prepared farm feed containing 1000 iu vitamin D3 and 3\% calcium. Their water intake was low in calcium and manganese (Table 3 ). In addition to receiving commercial vaccines, these fowl were also vaccinated with attenuated live IBV at 3, 6, 10, 15 and 20 weeks of age.

The roosters were killed with an overdose of chloral hydrate $(20 \%$ w/v i.p.) after which they were weighed. The 
Table 2. Occurrence of epididymal stones in unvaccinated White Leghorn roosters from Minas Gerais, Brazil and the respective drinking water hardness, body weight and testis-epididymis mass

\begin{tabular}{|c|c|c|c|c|c|c|c|}
\hline \multirow[b]{2}{*}{ Number $^{\mathrm{a}}$} & \multirow{2}{*}{$\begin{array}{c}\text { Age } \\
\text { (weeks) }\end{array}$} & \multirow{2}{*}{$\begin{array}{l}\text { Body weight } \\
\text { (g) }\end{array}$} & \multirow{2}{*}{$\begin{array}{c}\text { Testis-epididymis } \\
\text { mass (g) }\end{array}$} & \multirow{2}{*}{$\begin{array}{l}\text { Number of stones } \\
(x)\end{array}$} & \multicolumn{3}{|c|}{ Water hardness $\left(\mathrm{mg} \mathrm{l}^{-1}\right)$} \\
\hline & & & & & $\mathrm{Ca}$ & $M g$ & $\mathrm{~S}$ \\
\hline 1 & 82 & 1800.00 & 12.60 & 38.0 & 0.04 & 0.002 & 0.0 \\
\hline 2 & 82 & 1800.00 & 10.74 & 50.0 & 0.04 & 0.002 & 0.0 \\
\hline 3 & 82 & 1900.00 & 00.76 & 5.0 & 0.04 & 0.002 & 0.0 \\
\hline 4 & 82 & 1900.00 & 00.82 & 4.0 & 0.04 & 0.002 & 0.0 \\
\hline 5 & 90 & 2100.00 & 00.86 & NC & 0.04 & 0.002 & 0.0 \\
\hline 6 & 90 & 2100.00 & 00.64 & NC & 0.04 & 0.002 & 0.0 \\
\hline 7 & 90 & 1800.00 & 01.43 & NC & 0.04 & 0.002 & 0.0 \\
\hline 8 & 96 & 1750.00 & 01.62 & NC & 0.04 & 0.002 & 0.0 \\
\hline 9 & 96 & 1800.00 & 00.84 & NC & 0.04 & 0.002 & 0.0 \\
\hline 10 & 96 & 1850.00 & 00.97 & NC & 0.04 & 0.002 & 0.0 \\
\hline
\end{tabular}

${ }^{\mathrm{a}} 1-10=$ Belo Horizonte county; $(x)=$ means of both sides; NC = not counted.

Table 3. Occurrence of epididymal stones in IBV vaccinated Ross roosters from Minas Gerais, Brazil and the respective drinking water hardness, body weight and testis-epididymis mass

\begin{tabular}{|c|c|c|c|c|c|c|c|}
\hline \multirow[b]{2}{*}{ Number $^{\mathrm{a}}$} & \multirow{2}{*}{$\begin{array}{c}\text { Age } \\
\text { (weeks) }\end{array}$} & \multirow{2}{*}{$\begin{array}{l}\text { Body weight } \\
(\mathrm{g})\end{array}$} & \multirow{2}{*}{$\begin{array}{c}\text { Testis-epididymis } \\
\text { mass }(\mathrm{g})\end{array}$} & \multirow{2}{*}{$\begin{array}{l}\text { Number of stones } \\
\qquad(x)\end{array}$} & \multicolumn{3}{|c|}{ Water hardness $\left(\mathrm{mg} \mathrm{l}^{-1}\right)$} \\
\hline & & & & & $\mathrm{Ca}$ & $\mathrm{Mg}$ & $S$ \\
\hline 1 & 70 & 5200.00 & 14.99 & 28.0 & 0.04 & 0.002 & 0.0 \\
\hline 2 & 70 & 5100.00 & 19.63 & 26.5 & 0.04 & 0.002 & 0.0 \\
\hline 3 & 70 & 4800.00 & 17.71 & 24.5 & 0.04 & 0.002 & 0.0 \\
\hline
\end{tabular}

a $1-3$ = Carmo do Cajuru county; $(x)=$ means of both sides.

combined testis-epididymis were removed and weighed after fixation. The epididymides were processed for visualization of stones and for histology. Some stones were isolated for mineral microanalysis and blood was collected for ELISA analysis in order to detect antibodies to IBV.

\section{Visualization of epididymal stones}

The epididymal region was made transparent by clearing in glycerin so that stones could be viewed in situ. The tissues were fixed in $95 \%(\mathrm{v} / \mathrm{v})$ ethanol, transferred to $0.8 \%$ $(\mathrm{w} / \mathrm{v})$ sodium hydroxide for $24 \mathrm{~h}$, then to glycerin solutions $(1: 2,1: 1)$ and finally, to pure glycerin. After clearing, the epididymal region was viewed under a stereomicroscope with transmitted and incident light, and the stones were counted.

\section{Histology}

Fragments of the testis-epididymis and vas deferens were fixed by immersion in Bouin's fluid or neutral buffered formalin (NBF) for $24 \mathrm{~h}$ and were then processed for histology in glycol methacrylate (Historesin Leica) or paraffin wax. Sections of $2-5 \mu \mathrm{m}$ were obtained from the resin embedded tissue and stained with $1 \%(\mathrm{w} / \mathrm{v})$ Toluidine blue in $0.5 \%(\mathrm{w} / \mathrm{v})$ sodium borate or with periodic acid-Schiff (PAS) and counterstained with haematoxylin. Paraffin wax sections $(3-5 \mu \mathrm{m})$ were stained with haematoxylin-eosin, PAS and counterstained with haematoxylin, Alcian blue
$(\mathrm{pH} 2.5)$ and Alizarin red S methods of calcium detection (Bancroft and Cook, 1995). A few fragments of the epididymis were fixed in NBF and frozen at $-20^{\circ} \mathrm{C}$. Sections of $8 \mu \mathrm{m}$ were obtained in a cryostat and stained for lipid detection with Sudan black B and Sudan III (Bancroft and Cook, 1995). Other organs, such as kidney, submandibular salivary gland and trachea, were also examined for the occurrence of stones or microscopic alterations.

\section{Transmission electron microscopy}

Epididymal fragments were fixed in $2.5 \%(\mathrm{v} / \mathrm{v})$ glutaraldehyde in $0.1 \mathrm{~mol}$ cacodylate buffer $\mathrm{I}^{-1}(\mathrm{pH} 7.4)$ and processed for transmission electron microscopy. The fragments were post-fixed in $1.0 \%(\mathrm{w} / \mathrm{v})$ osmium tetroxide in 0.1 mol cacodylate buffer $\mathrm{I}^{-1}(\mathrm{pH} 7.4)$ and embedded in polybed 812 resin. Ultra-thin sections were stained with $2.0 \%(\mathrm{w} / \mathrm{v})$ uranyl acetate and lead citrate and viewed under a Zeiss 10 A electron microscope (Carl Zeiss Company, Jena) of the Centro de Microscopia Eletrônica da Universidade Federal de Minas Gerais (CEMEL).

\section{Microanalysis of stones}

The mineral composition of the stones was determined by collecting samples from the epididymides of two roosters from each group. These stones were analysed using an Energy Dispersive Spectrometer (EDS) and a Wavelength Dispersive Spectrometer (WDS) in the Laboratory of 
Electron Microscopy and Microanalyses of the Physics Department of the Federal University of Minas Gerais, Brazil. The EDS was used for both semi-quantitative and qualitative analysis; the latter approach allowed the identification of the various chemical elements. The WDS was used for X-ray image maps. The stones were embedded in transparent resin (Epon 825; Aldrich, St Louis, MO) and polished until the inner structure was revealed. They were then coated with gold for image and qualitative analysis or with carbon for semi-quantitative analysis. For the microprobe analysis, all measurements were performed on a JEOL JXA 8900 electron microprobe at 15 kV (Peabody, MA).

\section{Serology}

Blood from the unvaccinated crossbreed and White Leghorn roosters was collected from the brachial vein and allowed to clot at $37^{\circ} \mathrm{C}$ for $2 \mathrm{~h}$. Serum was separated and examined by an indirect ELISA (Idexx Laboratories, Portland, ME) to detect antibodies specific to IBV (Martins et al., 1991). Blood from vaccinated Ross roosters was examined quarterly by indirect ELISA to detect specific antibodies for IBV.

\section{Mineral analysis of water}

Samples used for the determination of the mineral concentration of the drinking water were examined by flame spectrometry (CETEC; Centro de Estudos Tecnologicos de Minas Gerais, Belo Horizonte).

\section{Identification of stones in the excreta}

Stones of intestinal, reproductive and ureteric origin were separated by washing the intestinal contents from the duodenum to the rectum and fluid from ureteric perfusion and excreta (500 g) of the White Leghorn roosters separately in running water and filtering through a wire mesh with $0.2 \mathrm{~mm}$ wide grids. The precipitate was stained by Alizarin red and examined under a stereomicroscope for the visualization of stones.

\section{Epididymal examination in other birds}

The epididymides from other domestic and wild birds were studied by clearing the tissues using the methodology described above. Domestic birds included: 64 domestic duck (Anas platyrhynchos), 10 coturnix quail (Coturnix coturnix), 9 domestic pigeon (Columba livia) and 6 turkeys (Meleagris gallopavo).

Wild birds included: 34 red-winged tinamou (Rhynchotus rufescens), 33 spotted tinamou (Nothura maculosa), 3 rheas (Rhea americana), 3 pied-billed grebes (Podilymbus podiceps), cormorant (Phalacrocorax olivaceus), little egret (Egretta thula), black vulture (Coragyps atratus), crested caracara (Polyborus plancus), roadside hawk (Buteo magnirostris), common guan (Penelope superciliaris), scaly dove (Scardafella squamata), blue-fronted parrot (Amazona aestiva), smooth-billed ani (Crotophaga ani), barn owl (Tyto alba), tropical screech owl (Otus choliva), burrowing owl
(Speotyto cunicularia), common potoo (Nyctibius giseus), pauraque (Nyctidromus albicollis), Amazon kingfisher (Chloroceryle amazona), giant toucan (Ramphastus toco) and green-barred woodpecker (Chrysoptilus melanochlorus).

All of these birds came from the collection preserved in the Laboratory of Birds Morphology at the Institute of Biological Sciences of the Federal University of Minas Gerais, Brazil. The wild birds were captured under the authorization of the Brazilian Institute for the Environment and Renewable Natural Resources (IBAMA), process numbers 5393/91 and 11200/98.

\section{Statistical analysis}

The relationship between testis-epididymal mass, number of stones and water hardness caused by calcium in the drinking water was performed by the Sperman correlation test (Zar, 1996).

\section{Results}

Efferent ductules of the epididymal region contained stones (Fig. 1a,b) in both reproductive tracts in $94.3 \%$ of the roosters examined (crossbreed, Ross and White Leghorn). The mean number of stones varied from 4 to 245.5 per animal (Table 1-3). Occasionally, the stones were also found in the epididymal duct (three roosters). However, with the exception of one kidney that presented a stone and a mononuclear cell infiltrate, stones or morphological alterations were not found in other organs examined. Surprisingly, stones were not found in the epididymal region of any other Brazilian domestic (4 species) or wild bird ( 21 species).

The stones found in the rooster efferent ductules were irregular in shape (Fig. 1c), with diameters ranging from 100 to $3000 \mu \mathrm{m}$ and ivory, yellow or light pink in colour. The smallest stones were either spherical or oval and an opaque centre could be seen using transmitted light. The largest stones were cylindrical or polymorphic. The surface of the stones varied from smooth to slightly rough or having sharppointed projections. The stones were hard in consistency and were easily detected by touch. When embedded in resin and polished for microanalysis, a central core surrounded by concentric and alternate layers of porous and compact material was evident (Fig. 2a,b).

X-ray microanalysis showed that the stones consisted of the following atoms by order of magnitude: calcium > oxygen > carbon, and very small amounts of sulphur, magnesium, sodium and phosphorus (Fig. 2c-f). The stone core contained a larger concentration of calcium and sulphur. The compact peripheral layers were formed mainly by calcium and the concentric porous layers showed similar composition to that of the core. The semi-quantitative analysis revealed that the stones consisted of approximately $43.5 \%$ calcium, $28.0 \%$ oxygen, $23.5 \%$ carbon, $1.0 \%$ sulphur, $0.3 \%$ magnesium, $0.3 \%$ sodium and $0.2 \%$ phosphorus (normalization factor $=0.2778$ ). 


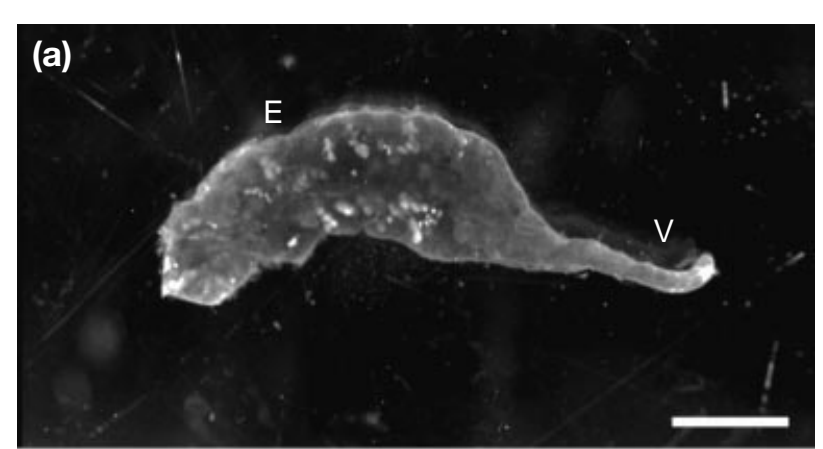

(b)
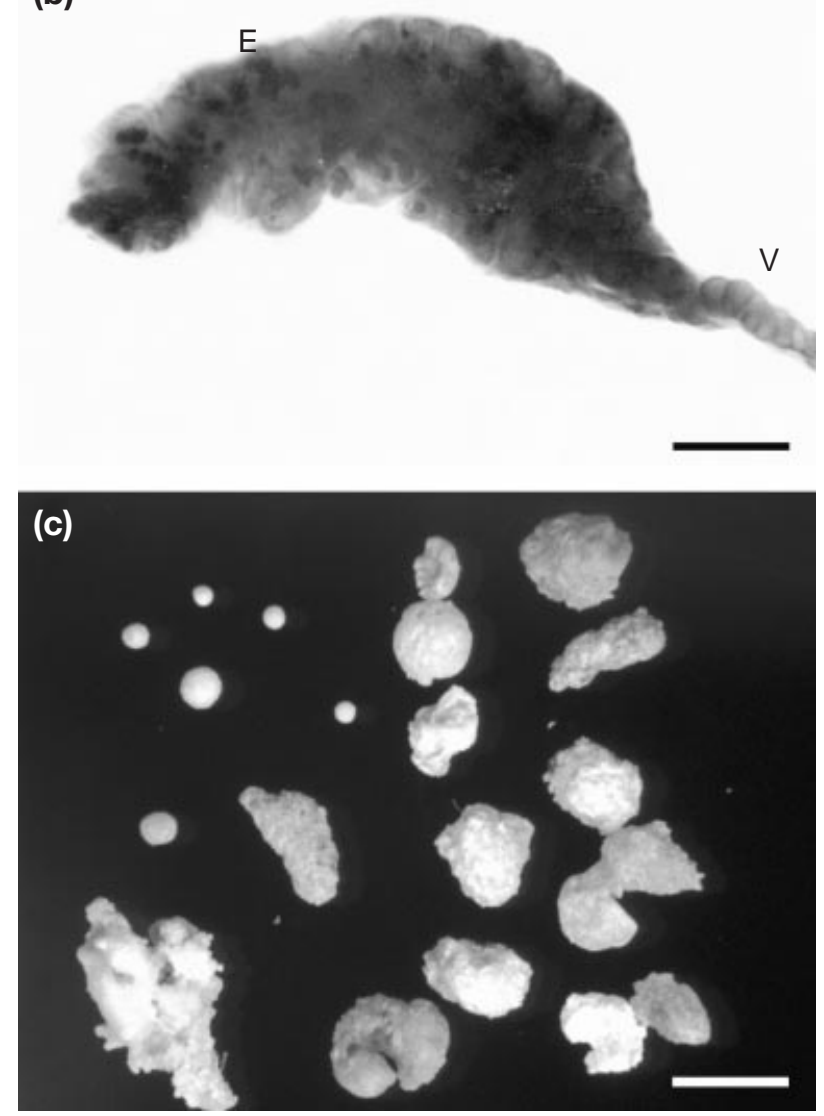

Fig. 1. Epididymal stones in the roosters. (a) A large number of stones (white spots) were found in the epididymal region (E) after clearing in glycerin and observing under incident light. $V$, vas deferens. (b) As seen by transmitted light, the epididymal stones are seen as dark spots into the cleared epididymal region. (c) Stones isolated from the efferent ductules are irregular in size and shape. Scale bars represent (a) $19 \mathrm{~mm}$, (b) $28 \mathrm{~mm}$ and (c) $350 \mu \mathrm{m}$.

Roosters not affected by epididymal lithiasis had efferent ductules of normal appearance, with tubules displaying an irregular lumen with a folded epithelium, lined by ciliated and non-ciliated cells. However, in all roosters with lithiasis, the efferent ductules showed alterations, although some areas appeared normal (Fig. 3a). In the least affected areas, the epithelium displayed small supranuclear vacuoles in non-ciliated cells (Fig. 3b). These vacuoles were negative for PAS and lipid staining (Sudan III and Sudan Black).
Alizarin red $\mathrm{S}$ staining revealed fine red intracellular inclusions also at the surface of the efferent ductules epithelial cells, indicative of calcification. Ciliated cells had no evident morphological alterations. In some areas, the efferent ductule epithelium was more severely damaged. The non-ciliated cells showed increases in vacuolization of the supranuclear cytoplasm (Fig. 3c-e), which was confirmed by electron microscopy. In tubules with more intense epithelial degeneration, the vacuoles occupied most of the cytoplasm (Fig. 3d,e). In the more advanced stages of degeneration, efferent ductule atrophy (Fig. 3f) was intense and the vacuolization and epithelial sloughing increased. In connective tissue of the epididymal region, especially next to the efferent ductules, a mononuclear cell inflammatory response was found in the affected birds (Fig. 3c,f). The extent of this mononuclear infiltration was variable and the inflammatory cellular response was not related to the testis-epididymis mass.

In the lumen of some efferent ductules there were variable numbers of spermatozoa and sloughed cells in addition to the stones (Fig. 4a). In addition, some acidophilic, PAS-positive and metachromatic compact masses of different sizes were noted (Fig. 4b-d). In some of these masses it was possible to identify the presence of sperm fragments and cell debris. Evidence of calcification of the luminal masses was detected by Alizarin staining (Fig. 4e,f). A calcification nidus was observed in the core of the masses, which appeared as small nuclei of concentric and alternate layers of organic and mineralized material (Fig. $4 g, h)$. The calcification of the peripheral portions was seen only in the larger luminal masses. At the cortical region, calcification centres showed the same pattern of concentric and alternate layers of organic material, the latter being identified by Toluidine blue. Occasional clumps of stones that were Alizarin-positive were also seen in the epididymal ductule, where they were found surrounded by PAS-positive and metachromatic mucous substances. Additionally, aggregates of calcified material were identified in the excreta but not in the intestinal contents or in fluid from the ureteric perfusion of the confined birds. The size and shape of the aggregates were similar to those of stones visualized in the efferent ductules and epididymal duct of roosters.

The luminal content (stones or compact masses) were partially surrounded by a thin envelope of squamous cells, continuous with the efferent ductule epithelium (Fig. 5a-c). The envelope isolated the content from the luminal compartment and left it in direct contact with the peritubular connective tissue (Fig. 5c-f). At the site of contact with the connective tissue, inflammatory cell aggregates were frequently observed (Fig. 5a,c,d). In addition, the original luminal content appeared degenerative in the connective tissue (Fig. 5f). At these sites, there was an intense inflammatory process and signs of fibrosis. Smaller efferent ductules were frequently seen surrounding the degenerating cell masses.

The testis-epididymis mass in the lithiasis-affected roosters was quite variable. Some roosters were of normal 

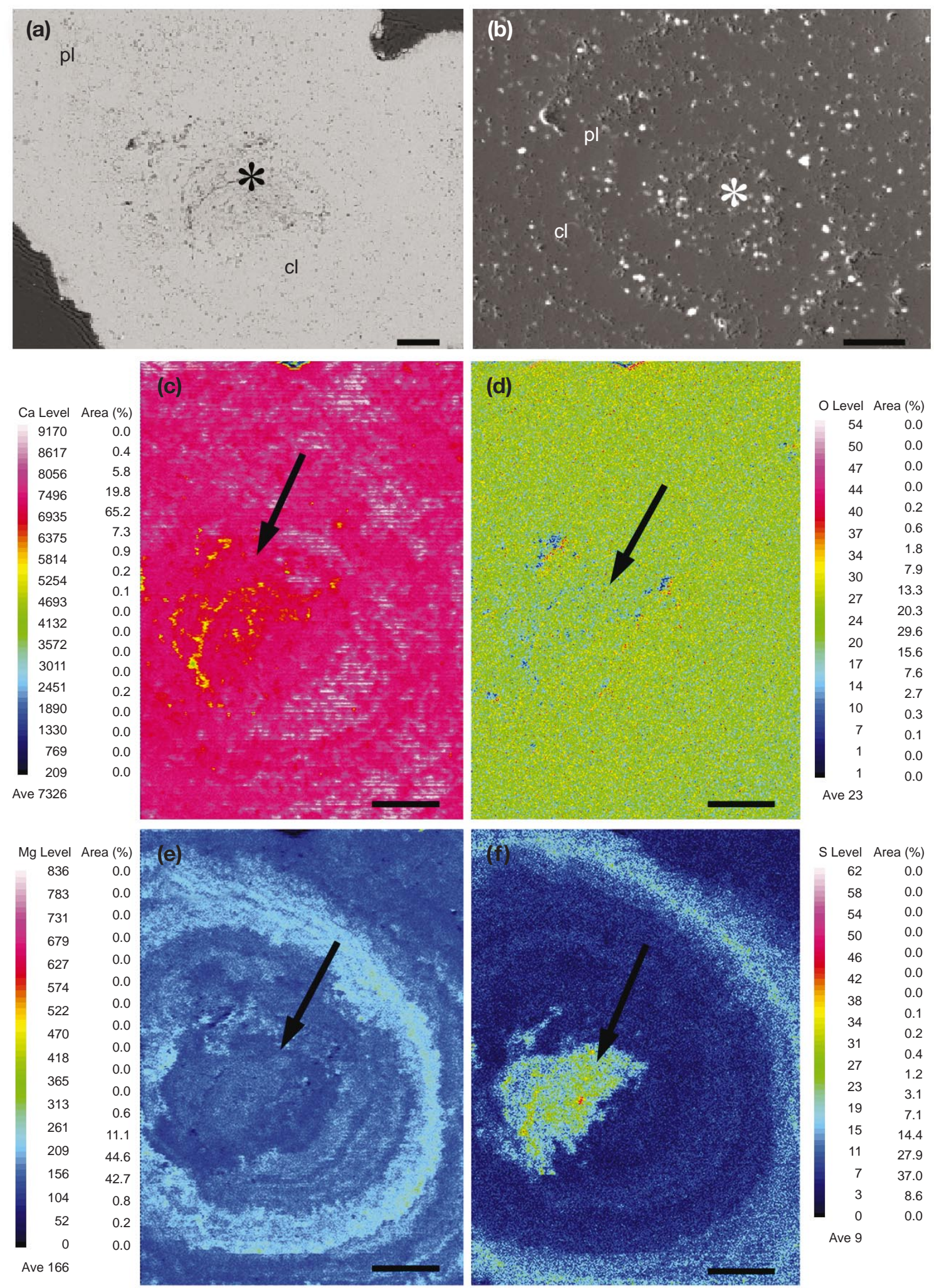

Fig. 2. Scanning electron microscopy and X-ray images of epididymal stones. (a) Backscattered scanning electron microscopy image of a stone showing a central core $(*)$ surrounded by concentric and alternate porous (pl) and compact (cl) layers. (b) Scanning electron secondary image of a stone showing the central core surrounded by concentric and alternate porous and compact layers. (c) X-ray image map of calcium in the epididymal stones. Yellow represents intermediate concentration and red represents higher concentration of calcium (see colour scale ranging on the left). Arrow shows the central core. (d) X-ray image map of oxygen in the epididymal stones, showing 

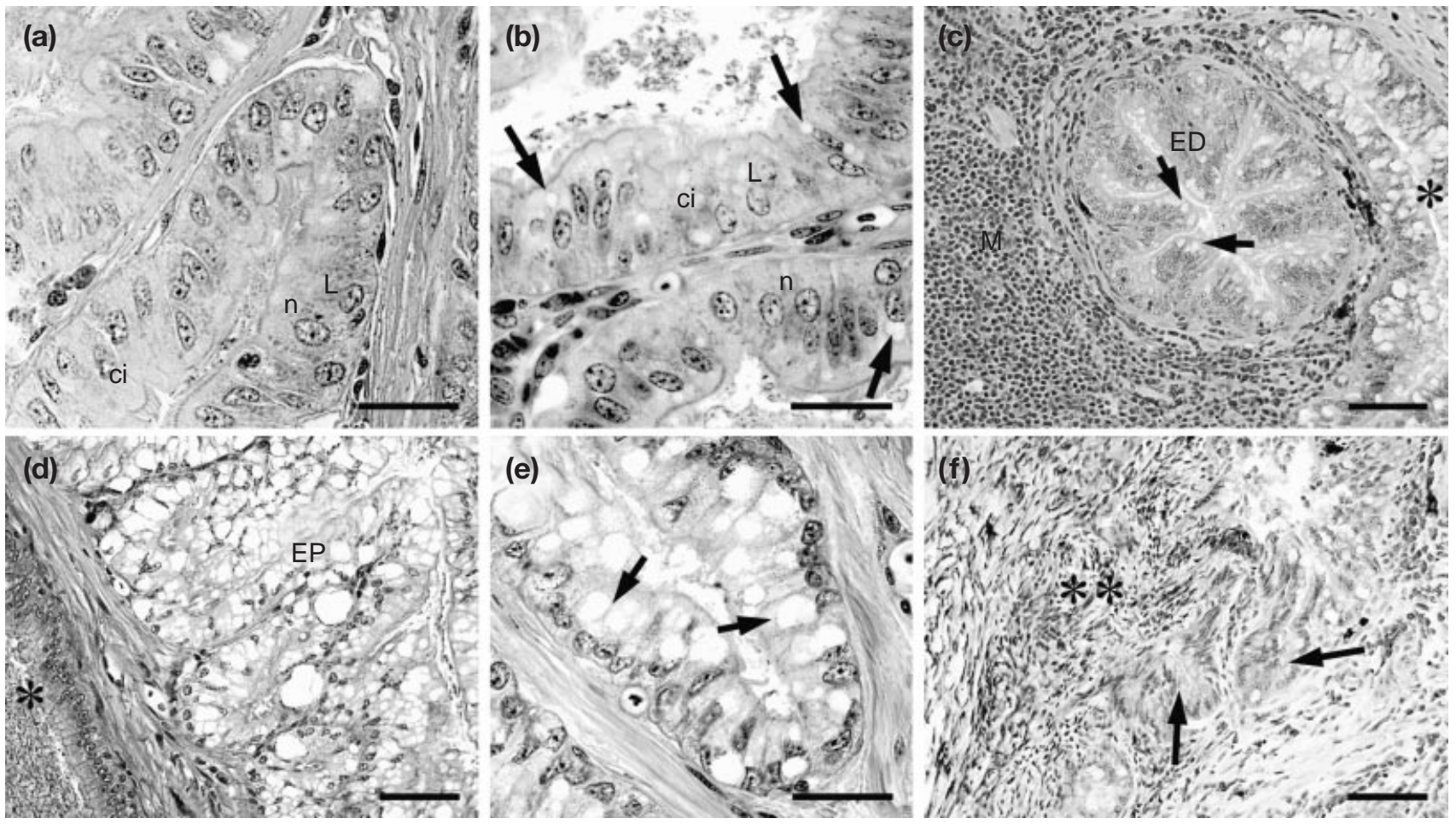

Fig. 3. Alterations in the efferent ductules epithelium of roosters with epididymal lithiasis. (a) Area of apparently normal efferent ductule showing folded epithelium with tall ciliated (ci) and non-ciliated cells (n). Few lysosomes (L) were found in the supranuclear cytoplasm. (b) In the least affected areas of the efferent ductules small and sparse cytoplasmic vacuoles (arrows) can be found in the epithelium. (c) An efferent ductule (ED) showing the characteristically folded epithelium is surrounded by a large mononuclear cell infiltration (M). At the apical cytoplasm some vacuoles (arrows) can be noted in the epithelial cells. Adjacent to this area there is a more affected efferent ductule ${ }^{*}$ ) showing epithelial cells that are intensely vacuolated. (d) In some areas of the affected efferent ductules, the epithelium (EP) is characterized by an intense vacuolization of the cell cytoplasm. An epididymal duct $(*)$ normal in appearance is seen adjacent to the altered efferent ductule. (e) At higher magnification it is seen that the cytoplasmic vacuoles (arrows) are mostly supranuclear in position. (f) In areas more severely affected by lithiasis there is an intense atrophy of the efferent ductules (arrows). Signs of fibrosis can be found in these areas $\left(^{* *}\right)$. Scale bars represent $(\mathrm{a}, \mathrm{b}, \mathrm{e}) 25 \mu \mathrm{m}$ and $(\mathrm{c}, \mathrm{d}, \mathrm{f}) 50 \mu \mathrm{m}$.

weight (19.6 g), whereas others were regressed and weighed less than $1.0 \mathrm{~g}$ (Tables 1-3). Regardless of the size, the testis-epididymis contained areas with different degrees of alteration (Fig. 6). The testes contained areas of normal appearance (Fig. 6a) as well as areas in which the seminiferous tubules showed variable degrees of epithelial cell sloughing and increased numbers of mononuclear leukocytes in the interstitial space (Fig. 6b-d). In some areas, most seminiferous tubules presented intense epithelial cell sloughing whereas the remaining epithelium was formed basically by Sertoli cells and by a few spermatogonia. These areas were also characterized by increased mononuclear cell infiltration, which made it difficult to distinguish the Leydig cells. The most severely affected testes showed regions displaying a loss of testicular architecture. In these areas, only a few seminiferous tubules were observed and the interstitial connective tissue was completely invaded by mononuclear cells, obscuring the Leydig cells (Fig. 6d). The remaining seminiferous tubules had smaller diameters and lumina occluded by sloughed cells.

The indirect ELISA tests for IBV were negative in crossbreed roosters, as well as in White Leghorn roosters. However, monitoring every 3 months for antibodies to IBV in the vaccinated Ross breeders using an indirect ELISA indicated the presence of serum antibodies in these roosters up to 70 weeks of age, at which time they were killed.

There was no significant correlation between the testisepididymis mass and calcium concentrations in the drinking water of the fowl ( $r s=0.6)$ (Fig. 7). There was no significant correlation between the number of stones in the efferent ductules and calcium concentrations in the drinking water $(r s=0.26)$ (Fig. 7).

homogeneous distribution of this element. Blue represents low concentration of oxygen in the core of the stone. Arrow shows the central core. (e) X-ray image map of magnesium in the epididymal stones. Blue is indicative of low concentration of magnesium, and dark blue represents the lowest concentration of this element. Arrow shows the central core. (f) X-ray image map of sulphur in the epididymal stones. A large amount of sulphur is found in the stone core (red points). From the core (arrow) to the periphery there is a gradient of decreasing concentration of sulphur revealed by the yellow and green colours, followed by pale blue and dark blue. Scale bars represent $50 \mu \mathrm{m}$. 

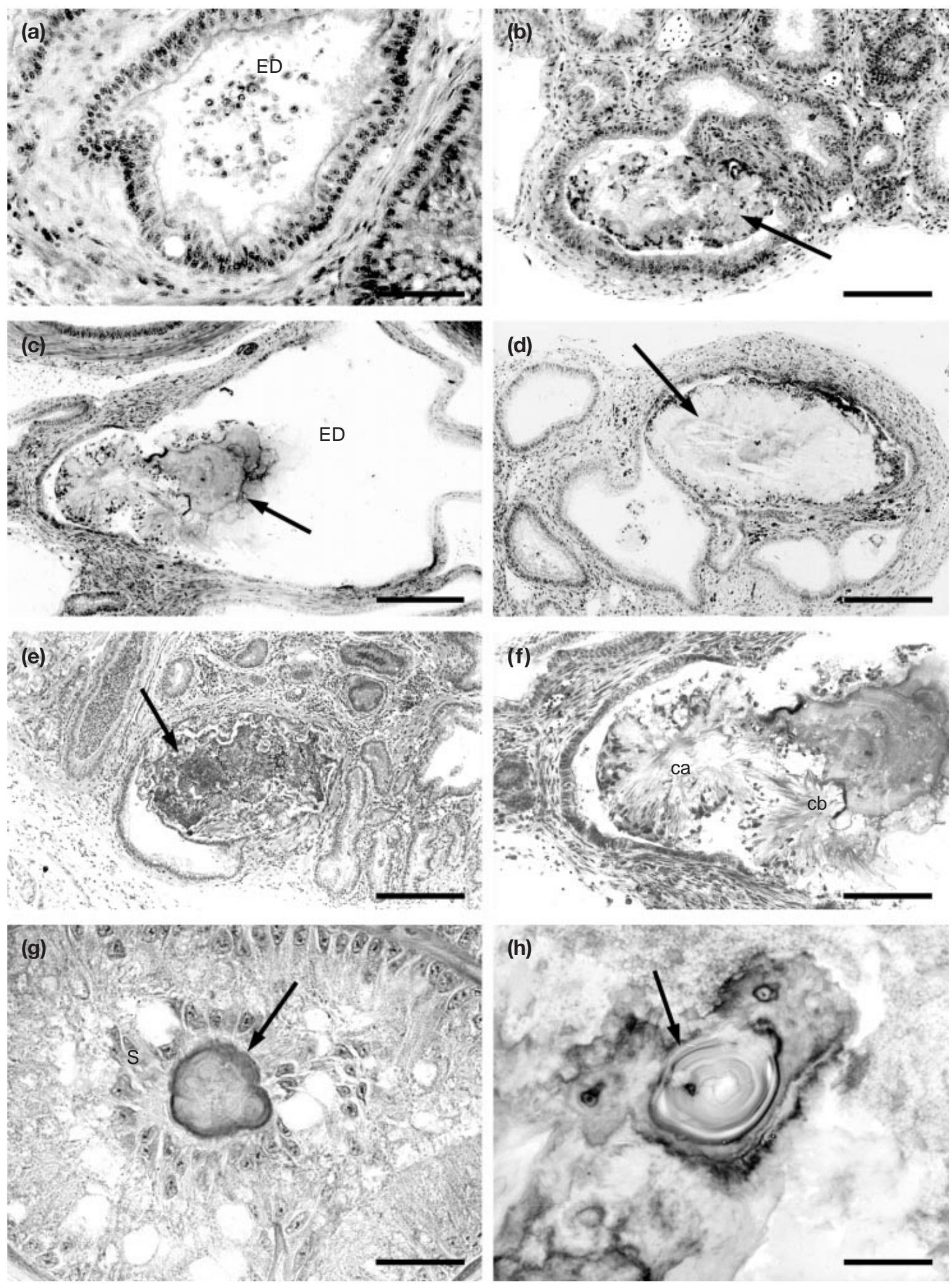

Fig. 4. Abnormal luminal content of the efferent ductules in lithiasis affected roosters. (a) Sloughed cells were frequently seen in the efferent ductules lumen (ED) of affected roosters. (b) The lumen of some efferent ductules is filled by a mass of amorphous material (arrow) that contains degenerating cells and cell debris. (c) The efferent ductule containing abnormal content (arrow) is in general dilated and the typical folding of the epithelium is lost. (d) The lumen of the efferent ductules 


\section{Discussion}

In the present study, a high incidence of stones (94.3\%) in the efferent ductules of several strains of roosters from different regions of the State of Minas Gerais, Brazil, was observed, confirming the wide geographical distribution of this dysfunction and indicating a worldwide occurrence. For the first time, other domestic and wild birds were examined and found not to have epididymal stones, indicating that this is a condition exclusive to roosters. The severity of the effect of epididymal lithiasis on the reproduction of roosters has been demonstrated, producing a significant reduction in fertility under natural and artificial insemination conditions (Janssen et al., 2000). Data on testicular morphology in the present study confirm that most of the affected birds show such severe testicular atrophy that infertility would be an expected result of this newly described abnormality.

The examination of other domestic and wild birds indicated that they do not exhibit epididymal lithiasis. This finding is important, because other than in the rooster epididymis (Janssen et al., 2000), lithiasis in the male genital system has been reported only in the human reproductive tract, including testis (Hobarth et al., 1992; Menchinelli et al., 1999; Thomas et al., 2000), rete testis, efferent ductules and epididymis (Coyne et al., 1994; Nistal et al., $1996 a, b)$. The pathogeny of human testicular lithiasis is not clear, but in a few cases it is associated with epididymal cysts (Hobarth et al., 1992, 1993). Janssen et al. (2000) reported the presence of epididymal cysts in 18- to 26week-old Leghorn roosters, which appeared to precede the stone formation. Cysts were not found in the present study. It is possible that the appearance of these cysts is the initial evidence of stone formation within the efferent ductules of the roosters. As the study examined roosters over 70 weeks of age, the alterations of the epididymal region were more advanced and the stones were larger (100-3000 $\mu \mathrm{m}$ compared with 9-160 $\mu \mathrm{m})$. In any case, as the rooster is the only known animal, other than humans, to have lithiasis of the genital system, it may serve as a biological model for investigations related to human male reproductive tract lithiasis.

The presence of stones in the epididymal duct of roosters, as opposed to the efferent ductules, was not a frequent finding. This might be attributed to the continuous flow of spermatic fluid, which is favoured by the progressive increase in diameter, and to the lack of folding of the epididymal mucosa (Tingari, 1971). The stones reaching the epididymal duct were enmeshed by mucous substances, which in addition to protecting the epithelial duct, could reduce attrition and facilitate the transit of the stones into the cloaca and excreta. The stones were confirmed by close examination of the cloacal excretions of birds under individual confinement. This point is emphasized because, if epididymal lithiasis is confirmed to originate from an infectious agent, the excrement could be a route of direct contamination among the roosters.

The mineral chemical composition seen in the present study is similar to those reported by Janssen et al. (2000). The small percentage differences in the mineral composition of the stones found between the two studies can be attributed to differences in the methodology used for the microanalysis. The previous study did not present data regarding the specific composition of organic material in the stones. However, the presence of oxygen, carbon and sulphur, which are associated with the metachromatic and PAS-positive reactions of the histological sections and revealed by the microanalysis of the stones in the present study, is an indication that organic material or its residues is present within the stones. This information could be essential for the elucidation of the mechanisms involved in calcium nucleation during the initiation of stone formation. The co-localization of sulphur and calcium within the core and in the peripheral concentric porous layers of the stones is strong evidence that these elements of organic material could act as a nucleation core for the formation of stones, as demonstrated in the genesis of pancreatic stones (Jing, 1990), salivary calculi (Hiraide and Nomura, 1980) and gallstones (Been et al., 1977). The exact role of the organic material associated with calcification centres is not clear, but it is well documented that proteins are incorporated within the renal stones and have an active role in the formation of stones (Binette and Binette, 1991; Siddiqui et al., 1998).

The efferent ductules are responsible for reabsorption of fluid from the testes and impairment of this function caused by diverse types of injury (Hess, 1998) leads to fluid accumulation and ultimately to fluid back-pressure, testicular atrophy and infertility. As seen in the present study, the presence of the stones or cell masses partially or totally occluded the rooster efferent ductule lumen. Therefore, the testicular alterations, including severe inflammation, massive cell sloughing and atrophy, could be secondary effects attributed to efferent ductule obstruction. The abnormal luminal content of the efferent ductules (stones and compacted masses) was frequently surrounded by a thin layer of squamous cells, which was continuous with the efferent ductule epithelium. This reaction of the epithelium to luminal content is called 're-canalization' and has been reported previously to occur in efferent ductules following obstructive lesions of the male excurrent ducts (Cooper and Jackson, 1973; Hess et al., 1991; Nakai et al.,

can be occluded by a compact mass (arrow) surrounded by cellular elements. (e) Calcification of the luminal content (arrow) was revealed by Alizarin S staining (dark staining). (f) In some ductules more than one calcification centre (ca,cb) can be found in the luminal mass after Alizarin S staining. (g) A small stone (arrow) surrounded by sloughed cells (S) is seen in the efferent ductule lumen. (h) In some luminal stones (arrow) the characteristic concentric layers surrounding a central core can be noted. Scale bars represent (a) $75 \mu \mathrm{m}$, (b) $150 \mu \mathrm{m},(\mathrm{c}-\mathrm{e})$ $200 \mu \mathrm{m},(\mathrm{f}) 12 \mu \mathrm{m},(\mathrm{g}) 25 \mu \mathrm{m}$ and (h) $15 \mu \mathrm{m}$. 

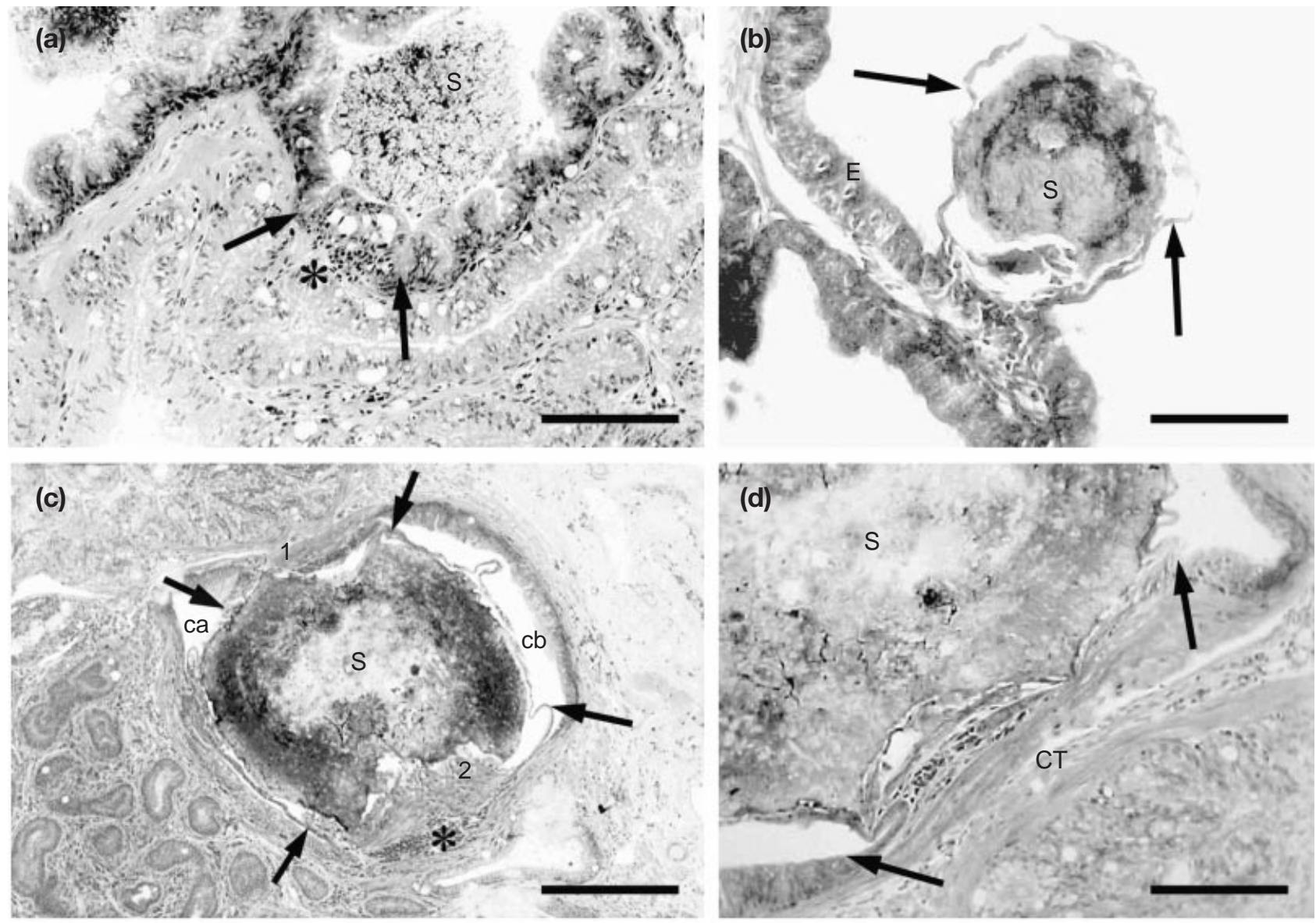

(e)
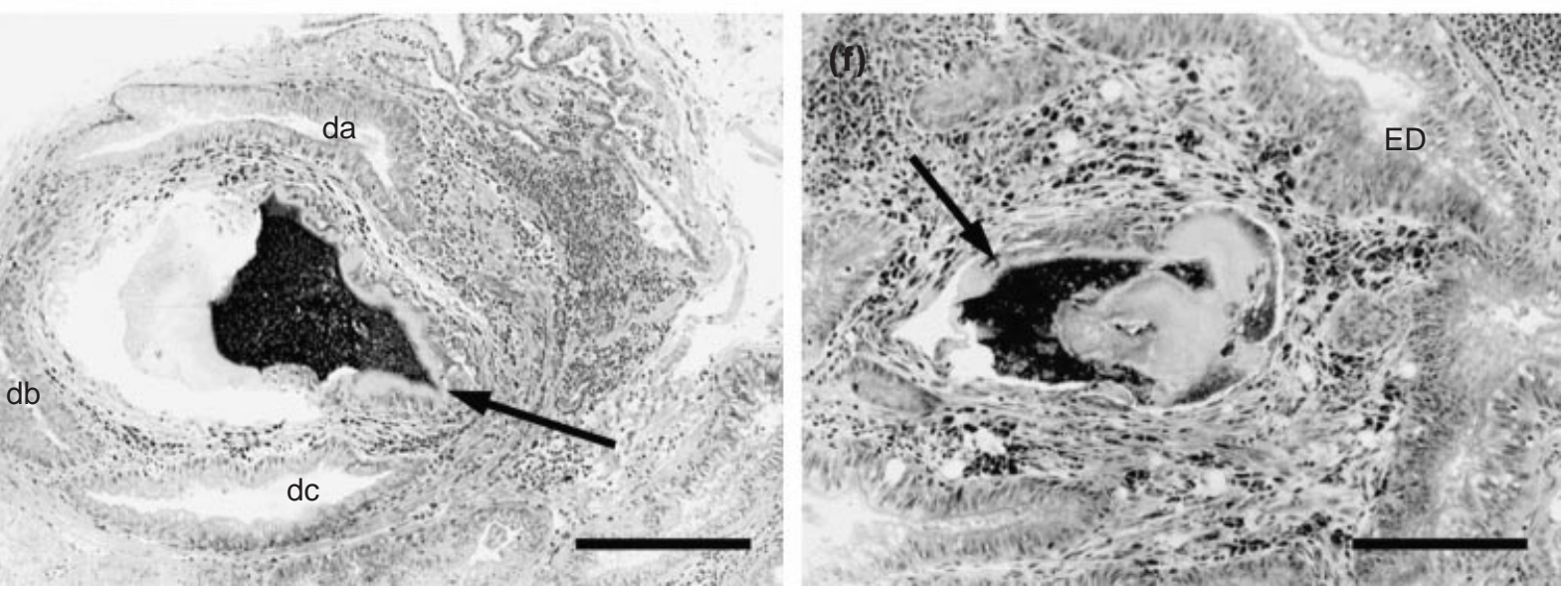

Fig. 5. Re-canalization of the efferent ductules. (a) At the beginning of the epithelial regrowth there is a rupture of the epithelium (area between the arrows) at the site of contact with the luminal content (S). Inflammatory infiltrate $\left(^{*}\right)$ is frequent at this site. (b) A small mass of luminal content is totally surrounded by a thin envelope of squamous cells (arrows) continuous with the efferent ductule epithelium (E). (c) Occlusion of the efferent ductules with large abnormal content resulted in rupture of the epithelium at more than one point $(1,2)$. The epithelial overgrowth along the edge of the occlusive content forms a thin envelope (arrows) that partially surrounds the luminal mass and fuses to the other side, resulting in the formation of two new channels (ca,cb). The original luminal content becomes incorporated into the connective tissue. At the site of contact with the connective tissue, aggregates of inflammatory cells $(*)$ appear. (d) Higher magnification shows a site of contact of the luminal content with the connective tissue (CT). Continuity between the efferent ductule tall epithelium and the thin envelope that surrounds the stone can be noted (arrows). (e) The stone (arrow) was isolated from the efferent ductule lumen and the original lumen was replaced by thin ductules (da,db,dc) probably the result of re-canalization. (f) Original luminal content (arrow) was found isolated in the connective tissue where it appeared degenerative. Adjacent to it, there are several efferent ductules (ED). Scale bars represent (a,b) $75 \mu \mathrm{m}$, (c) $200 \mu \mathrm{m}$, (d) $125 \mu \mathrm{m}$, (e) $140 \mu \mathrm{m}$ and (f) $100 \mu \mathrm{m}$. 

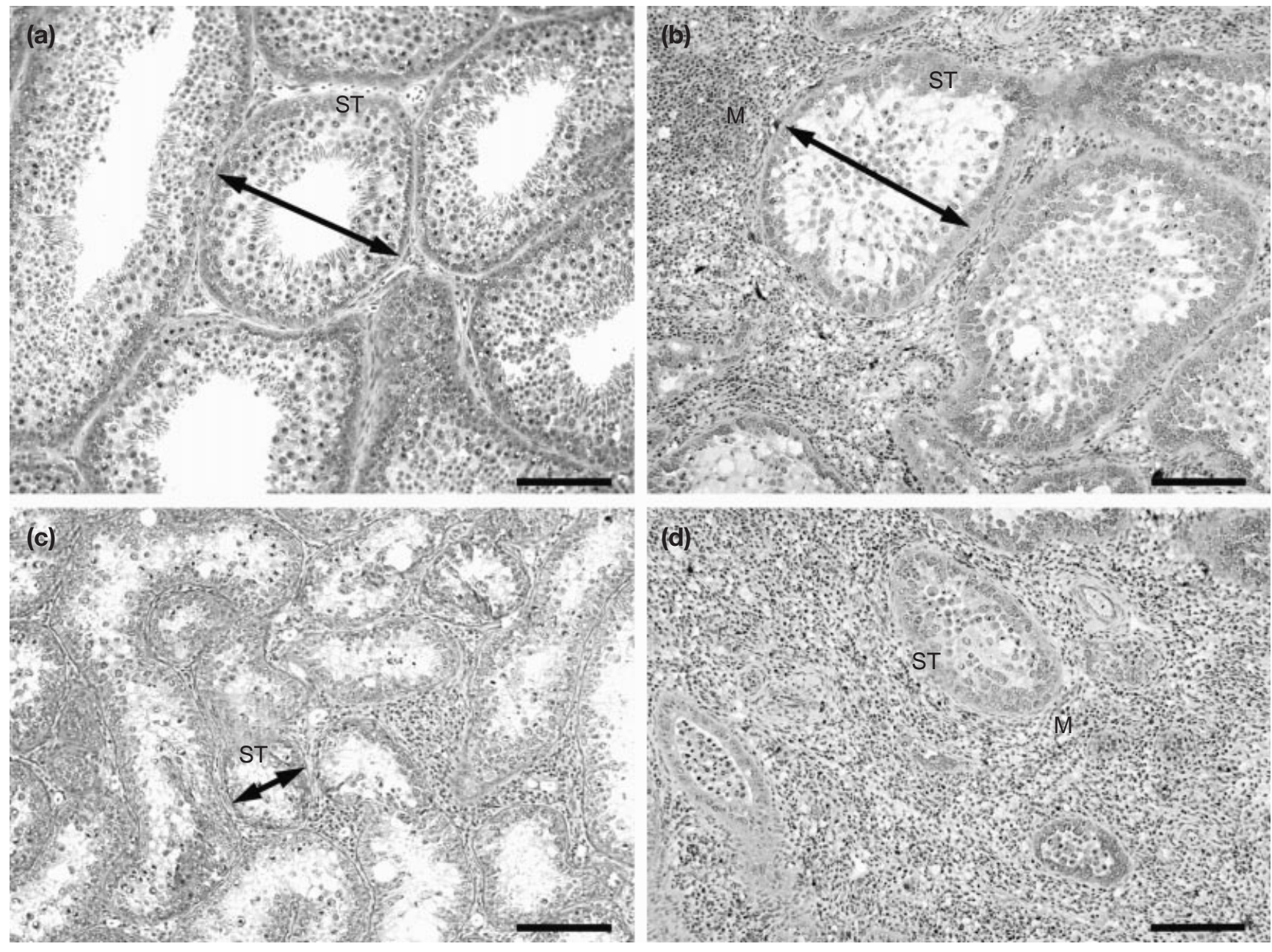

Fig. 6. Testicular morphology of the roosters affected by lithiasis. (a) Some testicular areas appeared normal in roosters affected by lithiasis. ST = seminiferous tubules. (b) In affected testis, the seminiferous tubules appeared dilated (double arrows) compared with the normal areas and showed intense cell sloughing. Pronounced mononuclear cell infiltration (M) is filling the intertubular compartment. (c) In more advanced stages of testis atrophy, the seminiferous tubules have small diameters (double arrow) and the epithelium is formed by Sertoli cells and a few spermatogonia. (d) In the most severely affected testis only a few atrophic seminiferous tubules are found and the interstitial connective tissue is completely occupied by mononuclear cells. Scale bars represent $100 \mu \mathrm{m}$.

1992, 1993). In this process, epithelial cells proliferate around the luminal content, resulting in its isolation from the lumen and incorporation into the connective tissue. This event would allow the free transit of testicular secretions through the genital ducts. However, Nakai et al. (1993) reported that the small newly formed ductules are abnormal and usually devoid of spermatozoa. A similar response has been shown experimentally in the rat kidney, but once in the connective tissue, the original luminal content can go through degeneration and be removed by macrophages (Kramer et al., 2000).

Vacuolization of the epithelial cells of the efferent ductules was present in all affected roosters and it seemed to increase with increased severity of the lesion. The nature of these vacuoles could not be determined. They were negative for glycoprotein (PAS) and lipid (Sudan black). They could represent an increase in endocytosis, as the apical cytoplasm of the non-ciliated cells is active in fluidphase, adsorptive and receptor-mediated endocytosis (Hermo and Morales, 1984; Hermo et al., 1985; Morales and Hermo, 1986).

The primary cause of the stone formation in the rooster efferent ductules is not known, but Janssen et al. (2000) have raised two hypotheses: (i) IBV, or (ii) high concentrations of vitamin D3 and calcium in the diet. The trimestral monitoring of IBV antibodies in Ross roosters revealed the presence of humoral antibodies against this disease. However, the negative results to the ELISA for IBV in crossbreed and in White Leghorn roosters show that these animals did not acquire infectious bronchitis, although they did develop epididymal lithiasis. Thus, there does not appear to be a relationship between IBV and the occurrence of epididymal lithiasis. However, the hypothesis of an infectious agent as the cause cannot be overlooked because 


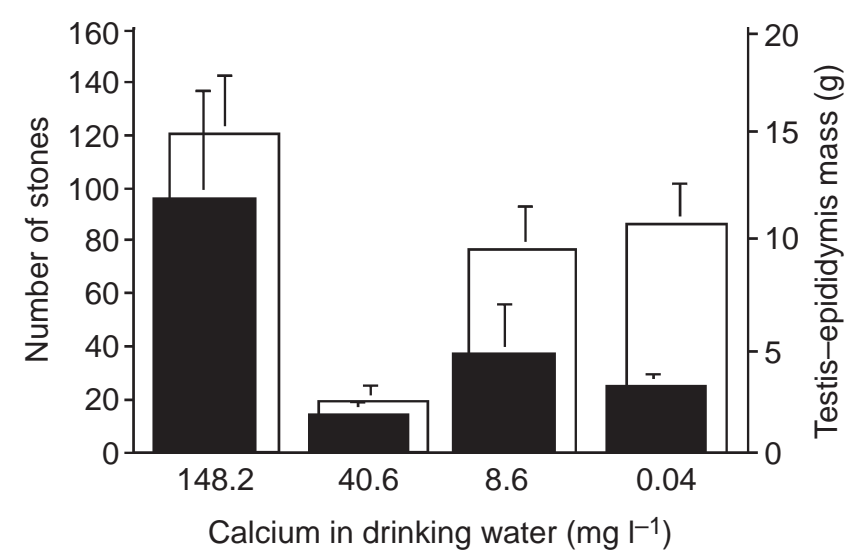

Fig. 7. Comparative analysis by Spearman test showed that there was no significant correlation between the testis-epididymis mass ( $\square$ ) and calcium concentrations in the drinking water of the fowl ( $r s=0.6)$, or between the number of stones $(\boldsymbol{\square})$ and calcium concentrations in the drinking water $(r s=0.26)$.

several infectious agents (virus, Chlamydia and bacteria) have been associated with calcification in tissues (Libby et al., 1997; Lin et al., 2000; Mayr et al., 2000), urolithiasis (Dumanski et al., 1994; Hokama et al., 2000; Huang et al., 1997; Ling et al., 1998) and gallstones (Allan et al., 1992; Panek et al., 2000).

Results from the present study show that the number of stones and the concentration of calcium in drinking water of the birds are not positively correlated. Likewise, ingested vitamin D3 does not appear to be related to stone formation, as the crossbreed roosters do not consume food containing high quantities of vitamin D3, but do develop epididymal lithiasis. Therefore, the vitamin D3 composition of the diet of the roosters affected by epididymal lithiasis does not seem to be consistent with the formation of stones. On the other hand, there is evidence that vitamin D3 is involved in the calcium homeostasis and that oestrogens also participate in the event (Arjmandi et al., 1993; Elaroussi et al., 1993; Wu et al., 1994; Johnson et al., 1996). Together with other known regulators such as parathyroid hormone, oestrogen acts as a modulator of vitamin D metabolism (Pike et al., 1978). Oestrogen can also regulate vitamin D3 receptor (VDR) expression (Liel et al., 1999; Kinuta et al., 2000; Schwartz et al., 2000). A large distribution of VDR is found in the male tract (Johnson et al., 1996) and is abundant in the efferent ductules (Stumpf et al., 1987; Schleicher et al., 1989). In addition, the rooster efferent ductules are the male tract segment that present the highest concentrations of oestrogen receptors (ER) in the male tract (Kwon et al., 1997). It may not be coincidental that the highest incidence of calcium stone formation is found in the organ that expresses the highest concentrations of oestrogen, ER and VDR. Impairment of one or more of these components could result in abnormal fluid reabsorption and calcium homeostasis, leading to stone formation in the efferent ductules. A micro-organism infection could be the factor that disrupts this homeostasis, but further supporting data will be needed to support this hypothesis.

The avian efferent ductules comprise over $70 \%$ of the epididymal region (Aire and Malmquist, 1979) and have a rate of fluid reabsorption much higher than in mammals $\left(100.4 \mu \mathrm{cm}^{-2} \mathrm{~h}^{-1}\right.$ compared with $17.2 \mu \mathrm{cm}^{-2} \mathrm{~h}^{-1}$ in rats) (Clulow et al., 1998). In mammals, fluid reabsorption of the efferent ductule is regulated by oestrogen (Hess et al., 1997). It is known that in rats a transitory increase in calcium concentration occurs from the rete testis $(0.9 \mathrm{mmol}$ $\left.\mathrm{I}^{-1}\right)$ to the conus vasculosus $\left(1.3 \mathrm{mmol} \mathrm{I}^{-1}\right)$ (Clulow et al., 1994) and a selective increase in calcium concentration induced by oestrogen is also described (Jenkins et al., 1983). These facts are indicative of a regulated concentration of calcium by reabsorption of fluid in the efferent ductules. It is intriguing that stones in the epididymal region are confined to the rooster, a species that was domesticated and has been intensely selected genetically for about 3000 years (Crawford, 1984; Etches, 1993), mostly for rapid growth and intense egg production. It is possible that the selective pressure to breed birds to mobilize calcium more efficiently, targeting egg and bone formation, may have resulted in a selective increase in the expression of a calcium binding protein, such as osteopontin (Iguchi et al., 1999), which is one of the matrix proteins associated with vitamin D-induced urolithiasis (Yasui et al., 2001). Such an increase could result in calcium deposition in the efferent ductules, the male organ that responds as equally well to oestrogen as does the female genital tract (Hess et al., 1997). Calcium mobilized into the efferent ductules could then result in the initiation of the calcium stone formation.

In conclusion, this study confirms and extends the information about the stones in the rooster epididymis, which appear to be unique for this species among birds. The similarities between the morphology and mineral composition of the stones, as well as the testicular-epididymal histopathological lesions seen in Brazilian roosters and those described by Janssen et al. (2000) confirm that the epididymal lithiasis is present in roosters around the world. The severity of the lesions found in the efferent ductules and testis indicates that this new male abnormality could have a potentially large economic impact on the poultry industry.

The authors would like to thank W. Tito Soares for technical assistance in the stones microanalysis and N. Rodrigo da Silva Martins for the ELISA test.

\section{References}

Aire TA and Malmquist M (1979) Intraepithelial lymphocytes in the excurrent ducts of the testis of the domestic fowl (Gallus domesticus). Acta Anatomica (Basel) 103 142-149

Allan DJ, Harmon BV and Robert SA (1992) Spermatogonial apoptosis has three morphologically recognizable phases and shows no circadian rhythm during normal spermatogenesis in the rat Cell Proliferation 25 $241-250$

Arjmandi BH, Salih MA, Herbert DC, Sims SH and Kalu DN (1993) Evidence for estrogen receptor-linked calcium transport in the intestine Bone and Mineral 21 63-74 
Bancroft JD and Cook HC (1995) Manual of Histological Techniques and their Diagnostic Application Livingstone, Edinburgh

Been JM, Bills PM and Lewis D (1977) Electron probe microanalysis in the study of gallstones Gut 18 836-842

Binette JP and Binette MB (1991) The matrix of urinary tract stones: protein composition, antigenicity, and ultrastructure Scanning Microscopy $\mathbf{5}$ 1029-1034; discussion 1034-1036

Clulow J, Jones RC and Hansen LA (1994) Micropuncture and cannulation studies of fluid composition and transport in the ductuli efferentes testis of the rat: comparisons with the homologous metanephric proximal tubule Experimental Physiology 79 915-928

Clulow J, Jones RC, Hansen LA and Man SY (1998) Fluid and electrolyte reabsorption in the ductuli efferentes testis Journal of Reproduction and Fertility Supplement 53 1-14

Cooper ER and Jackson H (1973) Chemically induced sperm retention cysts in the rat Journal of Reproduction and Fertility 34 445-449

Coyne J, al-Nakib L, Goldsmith D and O'Flynn K (1994) Secondary oxalosis and sperm granuloma of the epididymis Journal of Clinical Pathology $\mathbf{4 7}$ 470-471

Crawford RD (1984) Domestic fowl. In Evolution of the Domestic Animals pp 1-24 Ed. IL Mason. Longman Group, Harlow

Dumanski AJ, Hedelin H, Edin-Liljegreen A, Beauchemin D and McLean RJ (1994) Unique ability of the Proteus mirabilis capsule to enhance mineral growth in infectious urinary calculi Infection and Immunity $\mathbf{6 2}$ 2998-3003

Elaroussi MA, Forte LR, Eber SL and Biellier HV (1993) Adaptation of the kidney during reproduction: role of estrogen in the regulation of responsiveness to parathyroid hormone Poultry Science 72 1548-1556

Etches RR (1993) A genetic approach to physiology. In Manipulation of the Avian Genome pp 1-13 Eds RJ Etches and MV Gibbins. CRC, Boca Raton, Florida

Froman DP and Bernier PE (1987) Identification of heritable spermatozoal degeneration within the ductus deferens of the chicken (Gallus domesticus) Biology of Reproduction 37 969-977

Hermo L and Morales C (1984) Endocytosis in nonciliated epithelial cells of the ductuli efferentes in the rat American Journal of Anatomy 171 59-74

Hermo L, Clermont Y and Morales C (1985) Fluid-phase and adsorptive endocytosis in ciliated epithelial cells of the rat ductuli efferentes Anatomical Record 211 285-294

Hess RA (1998) Effects of environmental toxicants on the efferent ducts, epididymis and fertility Journal of Reproduction and Fertility Supplement $53247-259$

Hess RA, Moore BJ, Forrer J, Linder RE and Abuel-Atta AA (1991) The fungicide benomyl (methyl 1-(butylcarbamoyl)-2-benzimidazolecarbamate) causes testicular dysfunction by inducing the sloughing of germ cells and occlusion of efferent ductules Fundamentals and Applied Toxicology 17 733-745

Hess RA, Bunick D, Lee KH, Bahr J, Taylor JA, Korach KS and Lubahn DB (1997) A role for oestrogens in the male reproductive system Nature 390 509-512

Hiraide F and Nomura $\mathbf{Y}(1980)$ The fine surface structure and composition of salivary calculi Laryngoscope $\mathbf{9 0} 152-158$

Hobarth K, Susani M, Szabo N and Kratzik C (1992) Incidence of testicular microlithiasis Urology 40 464-467

Hobarth K, Szabo N, Klingler HC and Kratzik C (1993) Sonographic appearance of testicular microlithiasis European Urology 24 251-255

Hokama S, Toma C, Jahana $\mathrm{M}$, Iwanaga $\mathrm{M}$, Morozumi $\mathrm{M}$, Hatano $\mathrm{Y}$ and Ogawa $\mathbf{Y}$ (2000) Ascorbate conversion to oxalate in alkaline mileu and Proteus mirabilis culture Molecular Urology 4 321-328

Huang TH, Laux DE, Hamlin BC, Tran P, Tran H and Lubahn DB (1997) Identification of DNA methylation markers for human breast carcinomas using the methylation-sensitive restriction fingerprinting technique Cancer Research $\mathbf{5 7}$ 1030-1034

Iguchi M, Takamura C, Umekawa T, Kurita T and Kohri K (1999) Inhibitory effects of female sex hormones on urinary stone formation in rats Kidney International 56 479-485

Janssen SJ, Kirby JD, Hess RA, Rhoads M, Bunick D, Bailey KL, Parsons CM, Wang $\mathbf{H}$ and Bahr JM (2000) Identification of epididymal stones in diverse rooster populations Poultry Science 79 568-574
Jenkins AD, Lechene CP and Howards SS (1983) The effect of spironolactone on the elemental composition of the intraluminal fluids of the seminiferous tubules, rete testis and epididymis of the rat Journal of Urology 129 851-854

Jing ZP (1990) [Ultrastructure and elemental composition of pancreatic stones] Zhonghua Wai Ke Za Zhi 28 421-423, 446

Johnson JA, Grande JP, Roche PC and Kumar R (1996) Immunohistochemical detection and distribution of the 1,25-dihydroxyvitamin D3 receptor in rat reproductive tissues Histochemistry and Cell Biology 105 7-15

Kinuta K, Tanaka H, Moriwake T, Aya K, Kato S and Seino Y (2000) Vitamin $\mathrm{D}$ is an important factor in estrogen biosynthesis of both female and male gonads Endocrinology 141 1317-1324

Kirby JD, Froman DP, Engel HN, Jr, Bernier PE and Hess RA (1990) Decreased spermatozoal survivability associated with aberrant morphology of the ductuli efferentes proximales of the chicken (Gallus domesticus) Biology of Reproduction 42 383-389

Kramer G, Klingler HC and Steiner GE (2000) Role of bacteria in the development of kidney stones Current Opinion in Urology 10 35-38

Kwon S, Hess RA, Bunick D, Kirby JD and Bahr JM (1997) Estrogen receptors are present in the epididymis of the rooster Journal of Andrology 18 378-384

Libby P, Egan D and Skarlatos S (1997) Roles of infectious agents in atherosclerosis and restenosis: an assessment of the evidence and need for future research Circulation 96 4095-4103

Liel Y, Shany S, Smirnoff P and Schwartz B (1999) Estrogen increases 1,25dihydroxyvitamin $\mathrm{D}$ receptor expression and bioresponse in the rat duodenal mucosa Endocrinology 140 280-285

Lin TM, Jiang MJ, Eng HL, Shi GY, Lai LC, Huang BJ, Huang KY and Wu HL (2000) Experimental infection with bovine herpes virus-4 enhances atherosclerotic process in rabbits Laboratory Investigation 80 3-11

Ling GV, Franti CE, Johnson DL and Ruby AL (1998) Urolithiasis in dogs. IV: Survey of interrelations among breed, mineral composition, and anatomic location of calculi, and presence of urinary tract infection American Journal of Veterinary Research 59 650-660

Martins AM, Graubard Z, Merwe FV and Cartoon S (1991) The incidental demonstration of mesonephric duct remnants during hysterosalpingogram Acta Medica Portuguesa 4 35-36

Mayr M, Kiechl S, Willeit J, Wick G and Xu Q (2000) Infections, immunity, and atherosclerosis: associations of antibodies to Chlamydia pneumoniae, Helicobacter pylori and cytomegalovirus with immune reactions to heat-shock protein 60 and carotid or femoral atherosclerosis Circulation $102833-839$

Menchinelli P, De Giovanni L, Belli P, Manasia P, Weir JM and Ronzoni G (1999) Unilateral testicular microlithiasis Archivio Italiano di Urologia Andrologi 71 199-200

Morales C and Hermo L (1986) Intracellular pathways of endocytosed transferrin and non-specific tracers in epithelial cells lining the rete testis of the rat Cell and Tissue Research 245 323-330

Muncher Y, Sod-Moriah UA, Weil S, Rosenstrauch AW and Friedlander M (1995) Intratesticular retention of sperm and premature decline in fertility in the domestic rooster, Gallus domesticus. Journal of Experimental Zoology 273 76-81

Nakai M, Hess RA, Moore BJ, Guttroff RF, Strader LF and Linder RE (1992) Acute and long-term effects of a single dose of the fungicide carbendazim (methyl 2-benzimidazole carbamate) on the male reproductive system in the rat Journal of Andrology 13 507-518

Nakai M, Moore BJ and Hess RA (1993) Epithelial reorganization and irregular growth following carbendazim-induced injury of the efferent ductules of the rat testis Anatomical Record 235 51-60

Nistal M, Jimenez-Heffernan JA, Garcia-Viera M and Paniagua R (1996a) Cystic transformation and calcium oxalate deposits in rete testis and efferent ducts in dialysis patients Human Pathology 27 336-341

Nistal M, Mate A and Paniagua R (1996b) Cystic transformation of the rete testis American Journal of Surgical Pathology 20 1231-1239

Panek M, Lukasiewicz J, Kosowski K, Karczewska E, Heczko PB, Nowak K and Popiela T (2000) Adherence of bile-isolated bacteria to the bile ducts mucosa as a pathogenic factor in the development of inflammatory lesions Medical Science Monitor 6 291-299 
Pike JW, Spanos E, Colston KW, Maclntyre I and Haussler MR (1978) Influence of estrogen on renal vitamin D hydroxylases and serum 1alpha,25$(\mathrm{OH}) 2 \mathrm{D} 3$ in chicks American Journal of Physiology 235 E338-E343

Rosenstrauch A, Degen AA and Friedlander M (1994) Spermatozoa retention by Sertoli cells during the decline in fertility in aging roosters Biology of Reproduction 50 129-136

Schleicher G, Khan S and Nieschlag E (1989) Differentiation between androgen and estrogen receptor mediated effects of testosterone on FSH using androgen receptor deficient ( $\mathrm{Tfm})$ and normal mice Journal of Steroid Biochemistry and Molecular Biology 33 49-51

Schwartz BS, Lee BK, Lee GS, Stewart WF, Simon D, Kelsey K and Todd AC (2000) Associations of blood lead, dimercaptosuccinic acid-chelatable lead, and tibia lead with polymorphisms in the vitamin D receptor and [delta]-aminolevulinic acid dehydratase genes Environmental Health Perspectives 108 949-954

Siddiqui AA, Sultana T, Buchholz NP, Waqar MA and Talati J (1998) Proteins in renal stones and urine of stone formers Urological Research 26 383-388

Stumpf WE, Sar M, Chen K, Morin J and DeLuca HF (1987) Sertoli cells in the testis and epithelium of the ductuli efferentes are targets for $3 \mathrm{H}-1,25$ $(\mathrm{OH}) 2$ vitamin D3 Cell and Tissue Research 247 453-455
Thomas K, Wood SJ, Thompson AJ, Pilling D and Lewis-Jones DI (2000) The incidence and significance of testicular microlithiasis in a subfertile population British Journal of Radiology 73 494-497

Tingari MD (1971) On the structure of the epididymal region and ductus deferens of the domestic fowl (Gallus domesticus) Journal of Anatomy 109 423-435

Wu JC, Smith MW, Turvey A, Keable SJ and Colston KW (1994) Differential regulation of vitamin $\mathrm{D}$ receptor and intestinal calcium transpor occurring during sexual maturation in the fowl (Gallus domesticus) Comparative Biochemistry and Physiology Series A 109 713-720

Yasui T, Sato M, Fujita K, Ito Y, Nomura S and Kohri K (2001) Effects of allopurinol on renal stone formation and osteopontin expression in a rat urolithiasis model Nephron 87 170-176

Zar JH (1996) Biostatistical Analysis p. 662. Prentice Hall, New Jersey

Received 18 April 2002.

First decision 16 July 2002.

Revised manuscript received 27 August 2002.

Accepted 9 September 2002. 